Prosiding Seminar Nasional Teknologi Informasi dan Kedirgantaraan : Transformasi Teknologi untuk Mendukung Ketahanan Nasional, Yogyakarta, 13 Desember 2018

SENATIK 2018, Vol. IV, ISBN 978-602-52742-0-6

DOI: http://dx.doi.org/10.28989/senatik.v4i0.274

\title{
ANALYSIS OF CEISA SERVICES USER SATISFACTION USING THE EUCS METHOD IN THE DIRECTORATE GENERAL OF CUSTOMS AND EXCISE Muryan Awaludin ${ }^{1}$, Natasya Erent Yolanda ${ }^{2)}$ \\ Universitas Dirgantara Marsekal Suryadarma, STIKOM CKI \\ Jl. Protokol Halim Perdanakusuma Komplek Bandara, Halim Perdanakusuma Jakarta Timur 13610 - Indonesia \\ Email : ${ }^{1}$ muryanawaludin1@gmail.com, ${ }^{2}$ erent.natasya@gmail.com
}

\section{Abstract}

The purpose of this study is to analyze the factors that influence the satisfaction of users of CEISA services (Customs \& Excise Information System and Automation) at the Directorate General of Customs and Excise (DGCE). CEISA uses Single Sign-On (SSO) technology, meaning that users only do one login to be able to access all applications in accordance with their authority. Therefore, the CEISA database and server are centrally managed so that they can be accessed throughout the DGCE office. But in practice there are still DGCE offices that develop independent applications. User satisfaction is one of the important factors that influence the success of implementing an information system. This study uses the End-User Computing Satisfaction (EUCS) method as an indicator of research. The variables tested in this study were 100 respondents as samples taken from employees at the Tanjung Priok Type A Customs and Excise Service Office (CESO). Data analysis using Multiple Linear Regression Test with IBM SPSS Statistics 25 as a tool to process data. There are five hypotheses proposed in this study. The results showed that all proposed hypotheses were accepted. That is, all variables in the EUCS method have a positive and significant effect on CEISA service user satisfaction in the DGCE environment.

Keyword: User Satisfaction, End-User Computing Satisfaction (EUCS)

Abstrak

Tujuan dari penelitian ini adalah untuk menganalisis faktor-faktor yang mempengaruhi kepuasan pengguna layanan CEISA (Customs \& Excise Information System and Automation) pada Direktorat Jenderal Bea dan Cukai (DJBC). CEISA menggunakan teknologi Single Sign-On (SSO), artinya pengguna hanya melakukan sekali login untuk dapat mengakses seluruh aplikasi sesuai dengan kewenangannya. Oleh karena itu, basis data maupun server CEISA diatur secara terpusat sehingga dapat diakses diseluruh kantor DJBC. Namun pada praktiknya masih ada kantor-kantor DJBC yang mengembangkan aplikasi mandiri. Kepuasan pengguna merupakan salah satu faktor penting yang mempengaruhi keberhasilan penerapan suatu sistem informasi. Penelitian ini menggunakan metode End-User Computing Satisfaction (EUCS) sebagai indikator penelitian. Adapun variabel yang diuji dalam penelitian ini, 100 responden sebagai sampel yang diambil dari pegawai pada Kantor Pelayanan Utama Bea dan Cukai (KPUBC) Tipe A Tanjung Priok. Analisis data menggunakan Uji Regresi Linier Berganda dengan IBM SPSS Statistics 25 sebagai tools untuk mengolah data. Terdapat lima hipotesis yang diajukan dalam penelitian ini. Hasil penelitian menunjukkan bahwa semua hipotesis yang diajukan diterima. Artinya, seluruh variabel pada metode EUCS berpengaruh positif dan signifikan terhadap kepuasan pengguna layanan CEISA di lingkungan DJBC.

Kata Kunci: Kepuasan Pengguna, End-User Computing Satisfaction (EUCS) 


\section{Pendahuluan}

Meningkatnya ketergantungan organisasi pada teknologi informasi dan komunikasi untuk mencapai tujuan strategi dan kebutuhan organisasi menyebabkan tumbuhnya kebutuhan akan layanan teknologi informasi berkualitas tinggi yang mengikuti kebutuhan organisasi dan pengguna sesuai dengan perkembangannya. Agar sistem aplikasi yang digunakan menjadi efektif dalam kebutuhan organisasi, perlu dikembangkan pemahaman yang lebih baik terhadap faktor-faktor apa saja yang memengaruhi kesuksesan implementasi suatu sistem [1]. Salah satu faktor penting dalam menentukan keberhasilan penerapan suatu sistem informasi adalah kepuasan pengguna akhir sistem informasi. Pengguna akhir yang dimaksud adalah mereka yang terlibat langsung dalam penggunaan sistem informasi di dalam organisasi. Kepuasan pengguna (user satisfaction) menurut [2] didefinisikan sebagai suatu pendapat dari pengguna tentang aplikasi komputer tertentu, yang mereka gunakan. Sistem informasi suatu organisasi dapat diandalkan apabila memiliki kualitas yang baik dan mampu memberikan kepuasan pada pemakainya. Untuk mengetahui sejauh mana suatu sistem dapat dikatakan berkualitas tinggi, diperlukan evaluasi untuk membuktikan bahwa sistem tersebut diterima oleh penggunanya.

Saat ini banyak metode yang dapat digunakan untuk mengukur kepuasan pengguna sistem. Metode kepuasan pengguna yang paling banyak digunakan adalah EUCS yang dirumuskan oleh [2] dan User Information Satisfaction (UIS) yang dirumuskan oleh [3]. Berdasarkan penelitian [4] yang melakukan perbandingan antara instrumen EUCS dan UIS dihasilkan bahwa metode EUCS lebih mengungguli dalam mengukur kepuasan pengguna akhir sistem informasi dibandingkan metode UIS. Metode EUCS yang dikembangkan oleh [2] lebih menekankan kepuasan pengguna akhir terhadap aspek teknologi dengan menilai 5 (lima) komponen, yaitu isi (content), akurasi (accuracy), tampilan (format), kemudahan penggunaan (ease of use), dan ketepatan waktu (timeliness). Metode ini dinilai menjadi alat ukur kepuasan pengguna yang tepat karena memiliki instrumen pengukuran yang kompleks sehingga banyak digunakan sebagai acuan dalam berbagai penelitian.

CEISA merupakan sebuah wadah yang digunakan untuk menampung seluruh aplikasi yang telah dikembangkan. Jadi, seorang user dapat mengakses aplikasi sesuai dengan pekerjaan dan kewenangannya hanya dengan sekali login. CEISA dikembangkan pada tahun 2012 - 2014 dan digunakan hingga sekarang (tahun 2018).

Namun pada praktiknya, ditemukan bahwa masih ada kantor-kantor DJBC yang mengembangkan aplikasi mandiri. Artinya, kantor tersebut mengembangkan aplikasi yang tidak terintegrasi dengan CEISA.. Untuk mengetahui sejauh mana sistem yang diterapkan dapat dikatakan berhasil diperlukan evaluasi untuk membuktikannya [5]. Berdasarkan permasalahan tersebut, maka penulis ingin melakukan penelitian mengenai analisa tingkat kepuasan pengguna CEISA di lingkungan DJBC menggunakan metode EUCS dengan variabel ukur kelengkapan isi, keakuratan data, kesesuaian bentuk, kemudahan penggunaan sistem, dan ketepatan waktu akses

\section{Metodologi Penelitian}

\subsection{Desain Penelitian}

Desain penelitian pada penelitian ini menggunakan jenis penelitian korelasional (hubungan) dengan urutan sebagai berikut: 


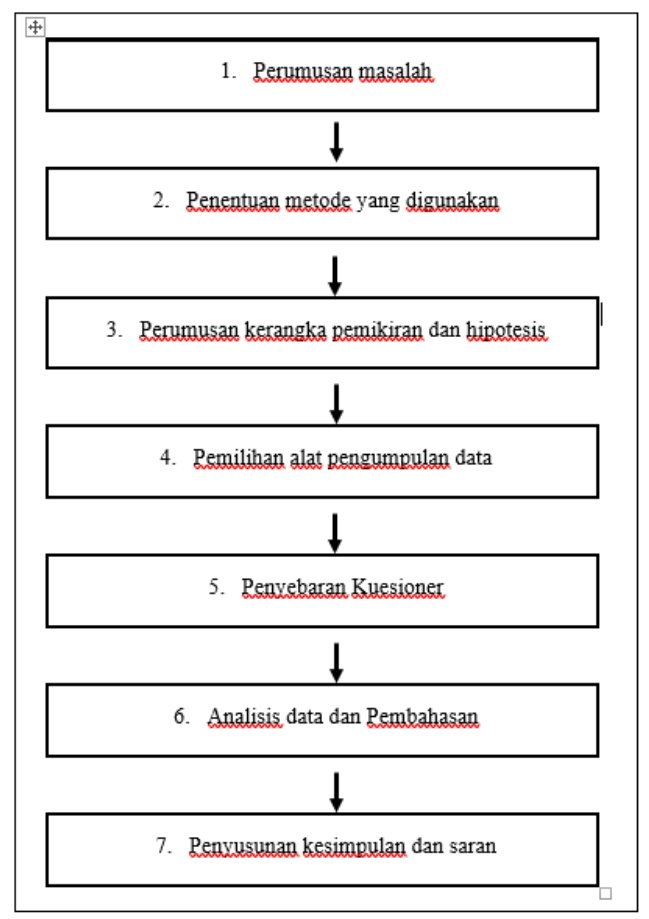

Gambar 1 Desain Penelitian

Penjelasan dari gambar desain penelitian di atas adalah sebagai berikut:

1. Merumuskan masalah.

Tahapan ini merumuskan permasalahan yang dihadapi, bisa tentang kekurangan ataupun kelebihan suatu obyek penelitian sehingga menarik untuk diteliti.

2. Metode yang digunakan.

Tahapan ini membahas tentang metode yang digunakan dalam penelitian, yaitu metode EUCS.

3. Merumuskan kerangka pemikiran dan hipotesis.

Tahapan ini membahas kerangka pemikiran penelitian serta hipotesis yang diajukan.

4. Memilih alat pengumpulan data dan menyebarkannya.

Tahapan ini peneliti memutuskan menggunakan kuesioner sebagai alat pengumpulan data yang akan disebar kepada responden.

5. Menganalisis data yang telah didapatkan dan menyajikannya.

Tahapan ini membahas analisis data yang telah terkumpul untuk menjawab rumusan masalah dan hipotesis yang diajukan.

6. Menyimpulkan hasil penelitian serta memberi saran terhadap penelitian selanjutnya.

Bentuk skala pengukuran yang diterapkan dalam penelitian ini mengacu pada skala Likert yang digunakan untuk mengukur kepuasan pengguna akhir terhadap sistem yang akan diteliti. Dalam penelitian ini, responden akan diberikan pertanyaan yang bersifat positif. Tabel 1 dapat menggambarkan penentuan skor untuk pilihan jawaban pada tiap pertanyaan atau pernyataan dalam kuesioner. 
Tabel 1. Skor Skala Likter

\begin{tabular}{|c|c|}
\hline Konteks & Nilai \\
\hline Sangat Setuju & 5 poin \\
\hline Setuju & 4 poin \\
\hline Netral & 3 poin \\
\hline Tidak Setuju & 2 poin \\
\hline Sangat Tidak Setuju & 1 poin \\
\hline
\end{tabular}

\subsection{Populasi dan Sampel}

Dalam penelitian ini, yang menjadi obyek penelitian adalah pemakai akhir sistem layanan CEISA pada Direktorat Jenderal Bea dan Cukai sebagai populasi penelitian. Berdasarkan data yang didapatkan, jumlah pegawai aktif pada Direktorat Jenderal Bea dan Cukai per Mei 2018 adalah sebesar 16.105 pegawai yang tersebar di Kantor Pusat, Kantor Pelayanan, dan Kantor Pengawasan Bea dan Cukai diseluruh Indonesia. Untuk memperoleh tanggapan dari responden, maka dari seluruh populasi tersebut diambil beberapa sampel.

Sampel merupakan sebagian dari populasi yang karakteristiknya hendak diteliti dan dianggap bisa mewakili keseluruhan populasi [6]. Peneliti melakukan pengambilan sampel dengan menggunakan teknik simple random sampling dimana semua anggota populasi mempunyai probabilitas atau kesempatan yang sama untuk dipilih menjadi sampel [7]. Simple random sampling termasuk dalam metode probability sampling dimana pengambilan sampel dari anggota populasi dilakukan secara acak tanpa memperhatikan strata atau tingkatan dalam anggota populasi tersebut.

Perhitungan sampel yang dipilih menggunakan Teori Slovin, yaitu

$\mathrm{n}=\mathrm{N} /\left(1+\mathrm{N} . \mathrm{e}^{\wedge} 2\right)$

dimana:

$\mathrm{n}=$ jumlah sampel

$\mathrm{N}=$ jumlah populasi

$\mathrm{e}=$ batas toleransi kesalahan

Batas toleransi kesalahan adalah 10\%. Semakin kecil toleransi kesalahan, semakin akurat sampel menggambarkan populasi. Jadi dengan jumlah populasi 16.105 orang pegawai dengan batas toleransi kesalahan $10 \%$, maka ukuran sampel penelitian adalah:

$$
\begin{aligned}
\mathrm{n}= & \mathrm{N} /(1+\mathrm{N} . \mathrm{e} 2) \\
& =16105 /\left(1+16105 \times 10 \%{ }^{\wedge} 2\right) \\
& =16105 /(1+16105 \times 0.01) \\
& =16105 /(1+161.05) \\
& =16105 /(162.05) \\
& =99.4
\end{aligned}
$$

Dikarenakan responden bukan pecahan, maka jumlah sampel dibulatkan menjadi 100 responden. Adapun sampel yang dipilih adalah pemakai akhir sistem layanan CEISA pada Kantor Pelayanan Utama Bea dan Cukai Tipe A Tanjung Priok yang diharapkan dapat mewakili populasi secara representatif. 


\subsection{Instrumen Penelitian}

Instrumen penelitian ini adalah sebuah kuesioner yang menjelaskan tentang pernyataan mengenai variabel-variabel yang hendak diteliti. Pernyataan penelitian terdiri dari 4 pertanyaan mengenai profil responden dan 19 pernyataan pengujian. Secara khusus, peneliti menggunakan lima poin skala Likert seperti yang telah dijelaskan pada sub bab sebelumnya. Setiap pernyataan disediakan lima alternatif jawaban, yaitu dari "sangat setuju" sampai dengan "sangat tidak setuju". Sementara untuk menjamin validitas dan reliabilitas kuesioner ini, peneliti menggunakan item indikator dari penelitian [2]. Tabel 2 menunjukkan indikator dan butir pernyataan pengujian.

Tabel 2. Indikator dan Butir Pernyataan Pengujian

\begin{tabular}{|c|c|c|c|}
\hline Variabel & Indikator & Definisi & Pernyataan \\
\hline \multirow[t]{3}{*}{ Content (isi) } & Relevansi & $\begin{array}{c}\text { Adanya kesesuaian } \\
\text { antara konten sistem dengan } \\
\text { kebutuhan pengguna }\end{array}$ & $\begin{array}{c}\text { Konten yang disajikan } \\
\text { sistem sesuai dengan } \\
\text { kebutuhan pekerjaan } \\
\text { saya }\end{array}$ \\
\hline & Manfaat & $\begin{array}{l}\text { Adanya manfaat yang } \\
\text { diberikan oleh konten yang } \\
\text { disajikan sistem kepada } \\
\text { pengguna }\end{array}$ & $\begin{array}{c}\text { Konten yang disajikan } \\
\text { sistem bermanfaat bagi } \\
\text { pekerjaan saya }\end{array}$ \\
\hline & Kualitas & $\begin{array}{c}\text { Tingkat } \\
\text { baik/buruknya konten sistem }\end{array}$ & $\begin{array}{c}\text { Konten sistem sudah } \\
\text { memiliki kualitas yang } \\
\text { baik }\end{array}$ \\
\hline \multirow[t]{4}{*}{$\begin{array}{c}\text { Accuracy } \\
\text { (keakuratan) }\end{array}$} & Akurasi & $\begin{array}{l}\text { Tingkat ketepatan } \\
\text { informasi yang dihasilkan } \\
\text { sistem }\end{array}$ & $\begin{array}{l}\text { Sistem menghasilkan } \\
\text { informasi yang akurat }\end{array}$ \\
\hline & Reliable & $\begin{array}{l}\text { Keandalan informasi } \\
\text { yang dihasilkan sistem }\end{array}$ & $\begin{array}{l}\text { Sistem menghasilkan } \\
\text { informasi yang } \\
\text { terpercaya }\end{array}$ \\
\hline & Standarisasi & $\begin{array}{c}\text { Kesesuaian sistem } \\
\text { dengan standar yang sudah } \\
\text { ditentukan }\end{array}$ & $\begin{array}{c}\text { Sistem bekerja sesuai } \\
\text { dengan standar yang } \\
\text { ditentukan }\end{array}$ \\
\hline & $\begin{array}{c}\text { Keselarasan } \\
\text { input dan output }\end{array}$ & $\begin{array}{c}\text { Tingkat kesesuaian } \\
\text { antara input dan output sistem }\end{array}$ & $\begin{array}{c}\text { Sistem menampilkan } \\
\text { output pada layar sesuai } \\
\text { dengan apa yang } \\
\text { diperintahkan }\end{array}$ \\
\hline \multirow[t]{3}{*}{$\begin{array}{l}\text { Format } \\
\text { (bentuk) }\end{array}$} & Menarik & $\begin{array}{c}\text { Tingkat } \\
\text { senang/tidaknya pengguna } \\
\text { terhadap tampilan sistem }\end{array}$ & $\begin{array}{l}\text { Desain tampilan sistem } \\
\text { menarik bagi saya }\end{array}$ \\
\hline & Jelas & $\begin{array}{l}\text { Tingkat kejelasan } \\
\text { tampilan sistem bagi } \\
\text { pengguna }\end{array}$ & $\begin{array}{c}\text { Desain tampilan sistem } \\
\text { sudah jelas }\end{array}$ \\
\hline & $\begin{array}{l}\text { Kemudahan } \\
\text { dalam } \\
\text { penggunaan }\end{array}$ & $\begin{array}{c}\text { Tingkat } \\
\text { mudah/tidaknya format } \\
\text { sistem saat digunakan oleh } \\
\text { pengguna }\end{array}$ & $\begin{array}{l}\text { Desain sistem mudah } \\
\text { digunakan }\end{array}$ \\
\hline
\end{tabular}




\begin{tabular}{|c|c|c|c|}
\hline Variabel & Indikator & Definisi & Pernyataan \\
\hline \multirow[t]{3}{*}{$\begin{array}{c}\text { Timeliness } \\
\text { (ketepatwakt } \\
\text { uan) }\end{array}$} & Up-to-date & $\begin{array}{r}\text { Informasi yang } \\
\text { disajikan terkini/tidak }\end{array}$ & $\begin{array}{c}\text { Sistem memberikan } \\
\text { informasi yang up-to- } \\
\text { date }\end{array}$ \\
\hline & $\begin{array}{l}\text { Ketersediaan } \\
\text { informasi }\end{array}$ & $\begin{array}{c}\text { Tingkat kesiapan informasi } \\
\text { yang ada pada sistem untuk } \\
\text { dapat digunakan oleh } \\
\text { pengguna dalam waktu } \\
\text { tertentu }\end{array}$ & $\begin{array}{c}\text { Sistem menyajikan } \\
\text { informasi secara tepat } \\
\text { waktu }\end{array}$ \\
\hline & Sistem service & $\begin{array}{l}\text { Kemampuan sistem } \\
\text { dalam memberikan layanan } \\
\text { kepada pengguna }\end{array}$ & $\begin{array}{c}\text { Sistem sudah didukung } \\
\text { tim layanan yang tepat } \\
\text { waktu }\end{array}$ \\
\hline \multirow[t]{3}{*}{$\begin{array}{l}\text { Ease of Use } \\
\text { (kemudahan } \\
\text { penggunaan) }\end{array}$} & $\begin{array}{l}\text { Kemudahan } \\
\text { dalam } \\
\text { penggunaan }\end{array}$ & $\begin{array}{c}\text { Tingkat } \\
\text { mudah/tidaknya sistem } \\
\text { digunakan oleh pengguna }\end{array}$ & $\begin{array}{l}\text { Sistem yang digunakan } \\
\text { sudah user-friendly }\end{array}$ \\
\hline & $\begin{array}{c}\text { Mudah } \\
\text { dioperasikan }\end{array}$ & $\begin{array}{c}\text { Tingkat } \\
\text { mudah/tidaknya pengguna } \\
\text { melakukan tindakan terhadap } \\
\text { sistem }\end{array}$ & $\begin{array}{l}\text { Sistem yang digunakan } \\
\text { mudah dioperasikan }\end{array}$ \\
\hline & Sistem service & $\begin{array}{l}\text { Kemampuan sistem } \\
\text { dalam memberikan layanan } \\
\text { bantuan kepada pengguna }\end{array}$ & $\begin{array}{c}\text { Sistem menyediakan } \\
\text { petunjuk pengoperasian } \\
\text { dalam penggunaannya }\end{array}$ \\
\hline \multirow{3}{*}{$\begin{array}{c}\text { User } \\
\text { Satisfaction } \\
\text { (kepuasan } \\
\text { pemakai) }\end{array}$} & Efektivitas & $\begin{array}{c}\text { Sistem yang dapat } \\
\text { membawa hasil (berhasil } \\
\text { guna) }\end{array}$ & $\begin{array}{l}\text { Secara keseluruhan, } \\
\text { sistem efektif dalam } \\
\text { penggunaannya }\end{array}$ \\
\hline & Efisiensi & $\begin{array}{l}\text { Sistem yang mampu } \\
\text { menjalankan tugas dengan } \\
\text { cermat dan tepat }\end{array}$ & $\begin{array}{c}\text { Secara keseluruhan, } \\
\text { sistem efisien dalam } \\
\text { penggunaannya }\end{array}$ \\
\hline & Kecukupan & $\begin{array}{l}\text { Sistem yang mampu } \\
\text { memenuhi kebutuhan dan } \\
\text { mendukung pekerjaan } \\
\text { pengguna }\end{array}$ & $\begin{array}{l}\text { Secara keseluruhan, } \\
\text { sistem memenuhi } \\
\text { kebutuhan dan } \\
\text { mendukung pekerjaan } \\
\text { saya }\end{array}$ \\
\hline
\end{tabular}

\subsection{Pengujian Instrumen Data}

a. Uji Validitas (Test of Validity)

Validitas adalah pengukuran yang menunjukkan tingkat ketepatan atau kecermatan suatu instrumen terhadap konsep yang diteliti. Suatu tes dapat dikatakan memiliki validitas yang tinggi jika memberikan hasil ukur yang tepat dan akurat sesuai dengan maksud dilakukannya tes tersebut [8]. Sebaliknya, validitas rendah mencerminkan bahwa instrumen kurang tepat untuk diterapkan. Alat ukur validitas yang tinggi berarti mempunyai varian kesalahan yang kecil, sehingga memberikan keyakinan bahwa data yang terkumpul merupakan data yang dapat dipercaya [9].

b. Uji Reliabilitas (Test of Reliability) 
Uji reliabilitas digunakan untuk mengetahui adanya konsistensi alat ukur dalam penggunaannya, atau dengan kata lain alat ukur tersebut mempunyai hasil yang konsisten apabila digunakan berkali-kali pada waktu yang berbeda [10]. Suatu kuesioner dikatakan reliabel jika jawaban seseorang terhadap pernyataan menghasilkan jawaban yang sama dari waktu ke waktu atau dalam kata lain konsisten atau stabil dari waktu ke waktu [11]. Pengujian ini dilakukan dengan menggunakan tenik Alpha Cronbach karena instrumen penelitian ini berbentuk angket atau skala bertingkat. Kriteria yang digunakan untuk menentukan suatu alat ukur reliabel atau tidak adalah pedoman Brown \& Thomson dengan ketentuan sebagai berikut:

$\alpha>0.7$ : dapat diandalkan

$\alpha<0.7$ : kurang dapat diandalkan

\subsection{Uji Regresi Linier Berganda}

Analisis regresi linier berganda digunakan untuk melihat pengaruh antara dua atau lebih variabel [12], yang dalam penelitian ini adalah variabel independen (content, accuracy, format, timeliness, ease of use) dengan variabel dependen (user satisfaction). Analisis ini untuk mengetahui arah hubungan antara variabel independen dengan variabel dependen apakah masing-masing variabel independen berhubungan positif atau negatif.

Model persamaan regeresi linier berganda adalah sebagai berikut:

$\mathrm{Y}=\mathrm{a}+\mathrm{b} 1 \mathrm{X} 1+\mathrm{b} 2 \mathrm{X} 2+\ldots+\mathrm{bnXn}$

Keterangan:

$\mathrm{Y}=$ variabel dependen (nilai yang diprediksikan)

$\mathrm{X}=$ variabel independen

$\mathrm{a}=$ konstanta $\mid \mathrm{b}=$ koefisien regresi (nilai peningkatan ataupun penurunan)

\subsection{Pengujian Hipotesis}

Uji t digunakan untuk mengetahui apakah variabel independen secara parsial berpengaruh signifikan terhadap variabel dependen. Hasil uji t dapat dilihat pada tabel coefficients pada kolom sig. dengan kriteria:

- Jika probabilitas < 0,05 maka dapat dikatakan bahwa secara parsial variabel independen berpengaruh signifikan terhadap variabel dependen.

- Jika probabilitas > 0,05 maka dapat dikatakan bahwa secara parsial variabel independen tidak berpengaruh signifikan terhadap variabel dependen

\section{Hasil Penelitian dan Pembahasan}

\subsection{Hasil Penelitian}

Kuesioner yang berisi 4 pertanyaan profil responden dan 19 pernyataan pengujian telah disebar pada Kantor Pelayanan Utama Bea dan Cukai Tipe A Tanjung Priok. Penyebaran kuesioner dilakukan pada bulan Juli 2018. Penyebaran kuesioner dilakukan secara tidak langsung yaitu dengan menyebarkan kuesioner melalui link akses google form. Untuk mengantisipasi adanya kekosongan jawaban pada kuesioner, maka setiap pertanyaan kuesioner dibuat mandatori sehingga responden tidak dapat meneruskan pengisian apabila terdapat jawaban yang kosong pada halaman pertanyaan. Dari kuesioner yang disebar, didapat 100 jawaban dari responden yang dipergunakan datanya untuk dianalisis. 


\subsection{Karekteristik Responden}

Adapun karakteristik responden dalam penelitian ini meliputi usia, pendidikan terakhir, jabatan, dan pengalaman menggunakan sistem CEISA.

1) Usia

Hasil dari analisa responden menunjukkan bahwa pengguna sistem terbanyak berada pada rentang usia 25 - 35 tahun yaitu sebesar $56 \%$ atau sebanyak 56 orang pegawai, diikuti responden berusia $<25$ tahun yaitu sebesar 32\% atau sebanyak 32 orang pegawai, responden berusia 36 - 45 tahun yaitu sebesar 9\% atau sebanyak 9 orang pegawai, dan responden berusia $>45$ tahun yaitu sebesar 3\% atau sebanyak 3 orang pegawai. Distribusi karakteristik responden berdasarkan usia dapat dilihat pada gambar berikut:

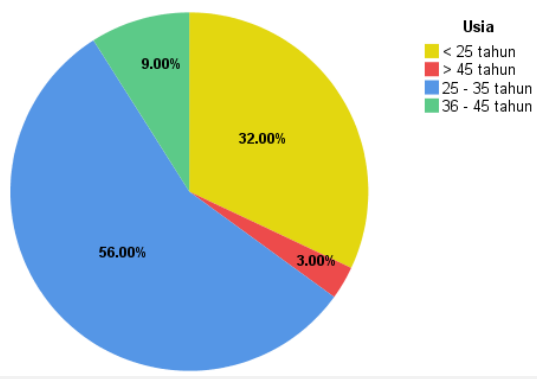

Gambar 2. Diagram Lingkaran Usia Responden

2) Pendidikan Terakhir

Berdasarkan hasil dari kuesioner yang telah disebar, pengguna sistem terbanyak dengan pendidikan terakhir D4/S1 yaitu sebesar 33\% atau sebanyak 33 orang pegawai, diikuti dengan pendidikan terakhir D3 sebesar 32\% atau sebanyak 32 orang pegawai, pendidikan terakhir SMA/SMK/D1 sebesar $21 \%$ atau sebanyak 21 orang pegawai, dan pendidikan terakhir S2/S3 sebesar $14 \%$ atau sebanyak 14 orang pegawai.



Gambar 3. Diagram Lingkaran Pendidikan Terakhir Responden

3) Jabatan

Dilihat pada gambar 4, diketahui bahwa pengguna sistem terbanyak berada pada jabatan Pelaksana yaitu sebesar $96 \%$ atau sebanyak 96 orang pegawai, diikuti dengan jabatan Eselon IV yaitu sebesar $4 \%$ atau sebanyak 4 orang pegawai. 


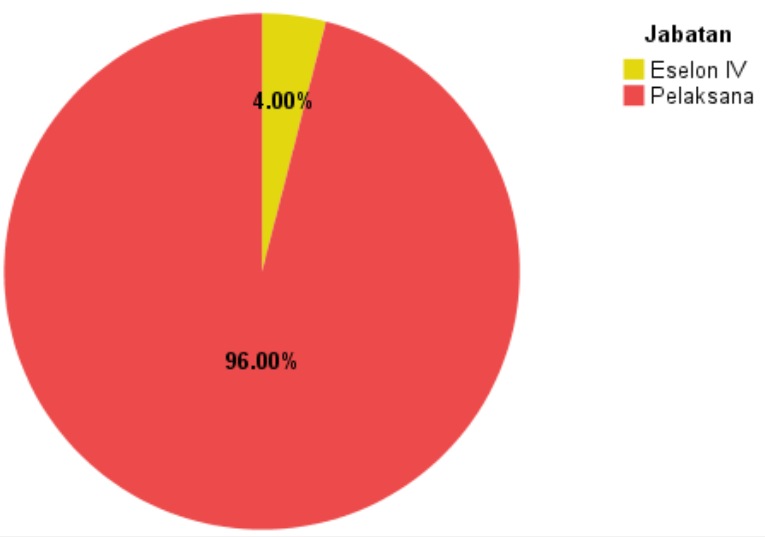

Gambar 4. Diagram Lingkaran Jabatan Responden

4) Pengalaman Menggunakan Sistem

Hasil dari penyebaran kuesioner didapat bahwa lama rata-rata responden menggunakan layanan CEISA, dimana jumlah responden terbesar diwakili oleh responden yang memiliki pengalaman selama lebih dari 3 tahun yaitu sebesar 58\% atau sebanyak 58 orang pegawai, diikuti oleh pegawai yang memiliki pengalaman $2-3$ tahun yaitu sebesar $30 \%$ atau sebanyak 30 orang pegawai, lalu responden dengan pengalaman $1-2$ tahun yaitu sebesar $12 \%$ atau sebanyak 12 orang pegawai.



Gambar 5. Diagram Lingkaran Pengalaman Responden

\subsection{Pengujian Instrumen Data}

\subsubsection{Uji Validitas}

Untuk menguji kehandalan kuesioner, peneliti melakukan uji validitas. Kuesioner yang peneliti gunakan sebagai alat ukur dalam penelitian ini diuji tingkat validitasnya dengan mengacu pada nilai rtabel, dimana nilai korelasi yang akan digunakan untuk mengukur validitas (rhitung) harus lebih besar dari nilai rtabel. Dalam penelitian ini $\mathrm{n}=30$, maka rtabel dengan taraf signifikansi 0.05 adalah 0.361 . Untuk membantu perhitungan validitas yang lebih akurat, dalam penelitian ini menggunakan perangkat lunak IBM SPSS Statistics 25. Berikut adalah tabel hasil uji validitas. 
Tabel 3. Hasil Uji Validitas Pra Survei

\begin{tabular}{|c|c|c|c|c|}
\hline Variabel & Indikator & $\overline{r_{\text {hitung }}}$ & $\mathbf{r}_{\text {tabel }}$ & Ket \\
\hline \multirow{3}{*}{ Content } & $\mathrm{C} 1$ & 0.718 & 0.361 & Valid \\
\hline & $\mathrm{C} 2$ & 0.633 & 0.361 & Valid \\
\hline & $\mathrm{C} 3$ & 0.740 & 0.361 & Valid \\
\hline \multirow{4}{*}{ Accuracy } & A1 & 0.441 & 0.361 & Valid \\
\hline & A2 & 0.735 & 0.361 & Valid \\
\hline & A3 & 0.578 & 0.361 & Valid \\
\hline & A4 & 0.632 & 0.361 & Valid \\
\hline \multirow{3}{*}{ Format } & $\overline{\mathrm{F} 1}$ & 0.854 & 0.361 & Valid \\
\hline & F2 & 0.837 & 0.361 & Valid \\
\hline & F3 & 0.844 & 0.361 & Valid \\
\hline \multirow{3}{*}{ Timeliness } & $\mathrm{T} 1$ & 0.665 & 0.361 & Valid \\
\hline & $\mathrm{T} 2$ & 0.607 & 0.361 & Valid \\
\hline & T3 & 0.759 & 0.361 & Valid \\
\hline \multirow{3}{*}{ Ease of Use } & $\overline{\mathrm{E} 1}$ & 0.802 & 0.361 & Valid \\
\hline & E2 & 0.667 & 0.361 & Valid \\
\hline & E3 & 0.808 & 0.361 & Valid \\
\hline \multirow{3}{*}{$\begin{array}{c}\text { User } \\
\text { Satisfaction }\end{array}$} & $\overline{\mathrm{U} 1}$ & 0.781 & 0.361 & Valid \\
\hline & U2 & 0.672 & 0.361 & Valid \\
\hline & U3 & 0.740 & 0.361 & Valid \\
\hline
\end{tabular}

Dari Tabel 3 di atas dapat dilihat bahwa nilai rhitung untuk setiap item pertanyaan adalah positif karena di atas nilai rtabelᄀ. Penjelasan untuk setiap variabel adalah sebagai berikut:

1. Content yaitu (C1) $0.718>0.361$, (C2) $0.633>0.361$, dan (C3) $0.740>0.361$. Dengan demikian semua item pertanyaan untuk variabel content, dengan indikator penilaian relevansi, manfaat, dan kualitas, dapat dinyatakan valid. Artinya pertanyaan-pertanyaan tersebut layak digunakan sebagai instrumen penelitian.

2. Accuracy yaitu (A1) $0.441>0.361$, (A2) $0.735>0.361$, (A3) $0.578>0.361$, dan (A4) $0.632>0.361$. Dengan demikian semua item pertanyaan untuk variabel accuracy, dengan indikator penilaian akurasi, reliable, standarisasi, dan keselarasan input output, dapat dinyatakan valid. Artinya pertanyaan-pertanyaan tersebut layak digunakan sebagai instrumen penelitian.

3. Format yaitu (F1) $0.854>0.361$, (F2) $0.837>0.361$, dan (F3) $0.844>0.361$. Dengan demikian semua item pertanyaan untuk variabel format, dengan indikator penilaian menarik, jelas, dan kemudahan dalam penggunaan, dapat dinyatakan valid. Artinya pertanyaanpertanyaan tersebut layak digunakan sebagai instrumen penelitian.

4. Timeliness yaitu (T1) $0.665>0.361$, (T2) $0.607>0.361$, dan (T3) $0.759>0.361$. Dengan demikian semua item pertanyaan untuk variabel timeliness, dengan indikator penilaian up-to-date, ketersediaan informasi, dan sistem service, dapat dinyatakan valid. Artinya pertanyaan-pertanyaan tersebut layak digunakan sebagai instrumen penelitian.

5. Ease of Use yaitu (E1) $0.802>0.361$, (E2) $0.667>0.361$, dan (E3) $0.808>0.361$. Dengan demikian semua item pertanyaan untuk variabel ease of use, dengan indikator 
kemudahan dalam penggunaan, mudah dioperasikan, dan sistem service, dapat dinyatakan valid. Artinya pertanyaan-pertanyaan tersebut layak digunakan sebagai instrumen penelitian.

6. User Satisfaction yaitu (U1) $0.781>0.361$, (U2) $0.672>0.361$, dan (U3) $0.740>0.361$. Dengan demikian semua item pertanyaan untuk variabel ease of use, dengan indikator kemudahan dalam penggunaan, mudah dioperasikan, dan sistem service, dapat dinyatakan valid. Artinya pertanyaan-pertanyaan tersebut layak digunakan sebagai instrumen penelitian.

\subsubsection{Uji t}

Uji t atau uji parsial digunakan untuk menunjukkan seberapa besar pengaruh variabel independen secara parsial terhadap variabel dependen. Berikut adalah hasil perhitungan untuk uji t:

Tabel 4. Tabel Uji t

\begin{tabular}{ccc}
\hline Variabel & t & \multicolumn{1}{l}{ Sig. } \\
\hline Content & 6.812 & .000 \\
\hline Accuracy & 6.494 & .000 \\
\hline Format & 7.538 & .000 \\
\hline Timeliness & 6.480 & .000 \\
\hline Ease of Use & 8.513 & .000 \\
\hline
\end{tabular}

Dari Tabel 4 di atas dapat dilihat bahwa semua variabel independen, yaitu content, accuracy, format, timeliness dan ease of use, mempengaruhi variabel dependen, user satisfaction, dimana $t$ hitung $>\mathrm{t}$ tabel 1.986 dengan tingkat signifikan $<0.05$. Artinya, semua hipotesis yang diajukan diterima.

\subsubsection{Hasil Analisis Uji Hipotesis}

Bagian ini akan memaparkan interpretasi berdasarkan hasil dari analisis uji t atau uji parsial. Berikut adalah pemaparan yang dilakukan dengan mengikuti hipotesis-hipotesis yang telah dirumuskan sebelumnya:

H1: Isi (content) berpengaruh signifikan terhadap kepuasan pengguna layanan CEISA.

Hasil uji t pada Tabel 4.3 menunjukkan bahwa variabel content mempengaruhi variabel user satisfaction dimanan $\mathrm{t}$ hitung (6.812) $>\mathrm{t}$ tabel (1.986). Ini berarti bahwa isi informasi sistem berpengaruh secara signifikan terhadap kepuasan pengguna layanan CEISA di lingkungan DJBC. Maka dapat disimpulkan bahwa H1 diterima.

H2: Akurasi (accuracy) berpengaruh signifikan terhadap kepuasan pengguna layanan CEISA.

Hasil uji t pada Tabel 4.3 menunjukkan bahwa variabel accuracy mempengaruhi variabel user satisfaction dimanan $t$ hitung (6.494) $>\mathrm{t}$ tabel (1.986). Ini berarti bahwa keakuratan sistem berpengaruh secara signifikan terhadap kepuasan pengguna layanan CEISA di lingkungan DJBC. Maka dapat disimpulkan bahwa $\mathrm{H} 2$ diterima.

H3: Tampilan (format) berpengaruh signifikan terhadap kepuasan pengguna layanan CEISA.

Hasil uji t pada Tabel 4.3 menunjukkan bahwa variabel format mempengaruhi variabel user satisfaction dimanan $\mathrm{t}$ hitung (7.538) $>\mathrm{t}$ tabel (1.986). Ini berarti bahwa tampilan sistem 
berpengaruh secara signifikan terhadap kepuasan pengguna layanan CEISA di lingkungan DJBC. Maka dapat disimpulkan bahwa H3 diterima.

H4: Ketepatan waktu (timeliness) berpengaruh signifikan terhadap kepuasan pengguna layanan CEISA.

Hasil uji t pada Tabel 4.3 menunjukkan bahwa variabel timeliness mempengaruhi variabel user satisfaction dimanan $t$ hitung (6.480) $>\mathrm{t}$ tabel (1.986). Ini berarti bahwa ketepatan waktu sistem dalam menyajikan informasi berpengaruh secara signifikan terhadap kepuasan pengguna layanan CEISA di lingkungan DJBC. Maka dapat disimpulkan bahwa H4 diterima.

\section{Kesimpulan}

Berdasarkan hasil temuan penelitian, berikut adalah kesimpulan dari penelitian ini:

1. Penelitian ini menunjukkan adanya pegaruh variabel EUCS terhadap kepuasan pengguna layanan CEISA di lingkungan DJBC. Variabel-variabel yang mempengaruhi kepuasan pengguna adalah sebagai berikut:

a. Variabel content berpengaruh positif terhadap kepuasan pengguna akhir.

b. Variabel accuracy berpengaruh positif terhadap kepuasan pengguna akhir.

c. Variabel format berpengaruh positif terhadap kepuasan pengguna akhir.

d. Variabel timeliness berpengaruh positif terhadap kepuasan pengguna akhir.

e. Variabel ease of use berpengaruh positif terhadap kepuasan pengguna akhir.

2. Semua hipotesis yang diajukan dalam penelitian ini diterima. Hasil analisis tentang pengujian hipotesis dapat disimpulkan sebagai berikut:

a. Penelitian ini menerima hipotesis H1 yang diajukan yaitu variabel isi (content) berpengaruh signifikan terhadap kepuasan pengguna layanan CEISA sehingga dapat disimpulkan bahwa isi informasi sistem secara individu memuaskan pengguna akhir layanan CEISA

b. Penelitian ini menerima hipotesis $\mathrm{H} 2$ yang diajukan yaitu variabel akurasi (accuracy) berpengaruh signifikan terhadap kepuasan pengguna layanan CEISA sehingga dapat disimpulkan bahwa keakuratan sistem secara individu memuaskan pengguna akhir layanan CEISA

c. Penelitian ini menerima hipotesis $\mathrm{H} 3$ yang diajukan yaitu variabel tampilan (format) berpengaruh signifikan terhadap kepuasan pengguna layanan CEISA sehingga dapat disimpulkan bahwa tampilan sistem secara individu memuaskan pengguna akhir layanan CEISA

d. Penelitian ini menerima hipotesis H4 yang diajukan yaitu variabel ketepatan waktu (timeliness) berpengaruh signifikan terhadap kepuasan pengguna layanan CEISA sehingga dapat disimpulkan bahwa ketepatan waktu sistem dalam menyajikan informasi secara individu memuaskan pengguna akhir layanan CEISA

e. Penelitian ini menerima hipotesis H5 yang diajukan yaitu variabel kemudahan penggunaan (ease of use) berpengaruh signifikan terhadap kepuasan pengguna layanan CEISA sehingga dapat disimpulkan bahwa kemudahan penggunaan sistem secara individu memuaskan pengguna akhir layanan CEISA 


\section{Daftar Pustaka}

[1] McHaney, R., Hightower, R., \& Pearson, J. (2002). A validation of the end-user computing satisfaction instrument in Taiwan. Information and Management, 39(6), 503-511.

[2] Doll, W. J., \& Torkzadeh, G. (1988). The Measurement of End-User Computing Satisfaction. MIS Quarterly, 12(2), 259.

[3] Ives, B., Olson, M. H., \& Baroudi, J. J. (1983). The Measurement of User Information Satisfaction. Communications of the ACM, 26, 785-793.

[4] Seddon, P., \& Yip, S.-K. (1989). An Empirical Evaluation of User Information Satisfaction (UIS) Measures for Use with General Ledger Accounting Software. Journal of Information System 6(1), 75-98.

[5] Fitriansyah, A., \& Harris, I. (2018). Pengukuran Kepuasan Pengguna Situs Web Dengan Metode End User Computing Satisfaction (EUCS). Jurnal Sistem Informasi, 2(1), 1-8.

[6] Harrison, A. W., \& Rainer Jr, R. K. (1992). The influence of individual differences on skill in end-user computing. Journal of Management Information Systems, 9(1), 93-111

[7] Lefkovits, C. H. C., Martin, E. C., Univac, S., Payden, K. D., Corporation, T. M., Connolly, J. T., ... Associates, K. (1976). A Status Report on the Activities of the Codasyl End User Facilities Committee FC ).

[8] DeLone, W. H., \& McLean, E. R. (1992). Information systems success: The quest for the dependent variable. Information Systems Research, 3(1), 60-95.

[9] Byun, D. H., \& Finnie, G. (2011). Evaluating usability, user satisfaction and intention to revisit for successful e-government websites. Electronic Government, an International Journal, 8(1), 1.

[10] Feoh, G., Linawati, \& Wirastuti, N. M. A. E. D. (2015). Indeks Kepuasan Pengguna Situs Web E-Gov Di Bali Dengan Metode EUCS dan CSI. Konferensi Nasional Sistem \& Informatika, 9-10.

[11] Koohi, E., Mohammad, E. N., Mohammadi, A., \& Koohi, A. (2016). The Study of Effective Reasons of the Customer Satisfaction Increase in the Acceptance and Use of Green Electronic Banking Services with EUCS Model (Case Study: Parsian Bank ), 4(4), 43-59.

[12] Lim, K., Lim, J.-S., \& Heinrichs, J. H. (2008). Validating an End-User Computing Satisfaction Instrument: A Confirmatory Factor Analysis Approach Using International Data. Journal of International Technology and Information Management, 17(2), 153165. 